\title{
Characteristics of Financial Technology as Financing Alternative Capitalization of Medium Small-Medium Enterprises (MSME)
}

\author{
Dwi Tatak Subagiyo ${ }^{1}$ \\ ${ }^{1}$ Faculty of Law, Wijaya Kusuma Surabaya University, Indonesia, E-mail: \\ tataksubagiyo@gmail.com
}

Submitted: October 7, 2020; Reviewed: November 18, 2020; Accepted: December 10, 2020

\begin{tabular}{|c|c|}
\hline Article Info & Abstract \\
\hline $\begin{array}{l}\text { Keywords: } \\
\text { Characteristics; } \quad \text { Financial } \\
\text { Technology; Micro, Small and } \\
\text { Medium Enterprises. } \\
\text { DOI: } \\
\text { 10.25041/fiatjustisia.v15no2.1933 }\end{array}$ & $\begin{array}{l}\text { Characteristics of Financial Technology as a } \\
\text { Financial Institution that uses information } \\
\text { technology to provide financial solutions by } \\
\text { prioritizing compliance with the principles of } \\
\text { prudence and risk management. The characteristics } \\
\text { of Financial Technology institutions are getting a } \\
\text { loan quickly; Makes Payment Easier; Make Loan } \\
\text { Payments without Additional Fees. Peer to Peer } \\
\text { Lending (P2Plending) system in providing financial } \\
\text { services is done through information technology } \\
\text { based.The financial services institution Peer to Peer } \\
\text { Lending (P2P Lending) is a financial technology } \\
\text { financial institution (Fintech). Financial } \\
\text { Technology (Fintech) as a Literacy Source for } \\
\text { Financing Micro, Small and Medium Enterprises; } \\
\text { Financial Technology (Fintech) As a Facilitator in } \\
\text { MSME Development; Financial Tecnology } \\
\text { (Fintech) as a driver for Micro, Small and Medium } \\
\text { Enterprises to Increase National Financial } \\
\text { Inclusion. The Role of the Financial Services } \\
\text { Authority (OJK) and the Indonesian Joint Funding } \\
\text { Fintech Association (AFPI) As Regulations and } \\
\text { Oversight of Financial Technology Institutions } \\
\text { (Fintech) in Indonesia. }\end{array}$ \\
\hline
\end{tabular}

\section{A. Introduction}

Economic development has several elements, including human resources, natural resources, capital, technology, and others, while one of the goals of development is to advance public welfare. Economic development is carried 
out sustainably and planned to produce a good condition, one of the ways is by developing Micro, Small and Medium Enterprises (MSMEs). ${ }^{1}$

Micro, Small and Medium Enterprises (MSMEs) have an important role, especially for economic development in this country. ${ }^{2}$

The activities of Micro, Small and Medium Enterprises during the monetary crisis occurred, were still able to survive and were able to become the backbone of the Indonesian economy at that time until now. The most important role of the existence of MSMEs is that they can create new jobs and allow the collection of taxes as state revenue. ${ }^{3}$

MSMEs are considered to create jobs faster than other large business sectors, another major contribution is that MSMEs have an important role in exports and international trade so that they can become a buffer in contributing to the country's foreign exchange. ${ }^{4}$

In the last few years, the growth of MSMEs itself has begun to develop very rapidly. ${ }^{5}$

And that causes a shift in the mindset of the community, from the mindset as an employee or employee to an entrepreneur. ${ }^{6}$

The number of Micro, Small and Medium Enterprises has now reached 99.9\%, consisting of $93.4 \%$ of Small Businesses, 5.1\% and Medium Businesses, and it is expected that the number should be increased so that not only small businesses also but also at the mid-level business and labor absorption reached 97\%. Besides that, Micro, Small and Medium Enterprises also contributed up to $97 \%$ of GDP. ${ }^{7}$

The contribution of MSMEs to Indonesia's Gross Domestic Product (GDP) can be said to be quite large, reaching $61.41 \%$ and able to absorb up to $96.71 \%$ labor force in $2017 .{ }^{8}$

\footnotetext{
${ }^{1}$ Lia Amalia, Ekonomi Pembangunan (Yogyakarta: Graha Ilmu, 2007), 1.

${ }^{2}$ R. M. K. Rahardjo, "Faktor Pendukung Keputusan UMKM Dalam Mengambil Modal Usaha Dengan Model Peer-To-Peer (P2P) Lending”, Jurnal Nasional Edusainstek 2, no. 1 (2019): 438-445.

${ }^{3}$ A. H. K. Sucahyawati, "Dimensi Kreativitas dan Pengembangan Usaha Mikro Kecil dan Menengah (UMKM)", Jurnal Hummansi 2, no. 1 (2019): 25-36.

${ }^{4}$ N. V. F. A. Setiawan, "Peran Keunggulan Bersaing Dalam Memediasi Dampak Orientasi Pasar Dan Orientasi Kewirausahaan Terhadap Kinerja UMKM". Majalah Ilmiah 18, no. 1, (2018), 54-70, DOI: 10.1017/CBO9781107415324.004.

5 D. Luckandi, "Analisis Transaksi Pembayaran Menggunakan Fintech Pada UMKM di Indonesia: Pendekatan Adaptive Structuration Theory", Jurnal Informatika dan Komputer 4, no. 1 (2019): 1-10.

${ }^{6}$ Mulyadi Nitisusastro, Kewirausahaan dan Manajemen Usaha kecil, Cet II. (Bandung: Alfabeta, 2012), 39.

${ }^{7}$ www.google.com/amp/s/m.liputan6.com/amp/3581067/, Accessed on April 20, 2018.

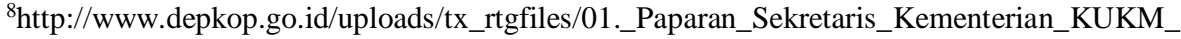
02.pdf., Accessed on April 20, 2018.
} 
Meanwhile, the number of actors running MSME businesses was recorded at 60 million business actors in 2019 with so many players, of course, has the potential to absorb a large number of workers. ${ }^{9}$

In addition, the national and regional economies continue to increase, this is because MSMEs are able to support the national economy, therefore the existence, resilience or contribution of these MSMEs continues to increase and cannot be doubted. ${ }^{10}$

Micro, Small and Medium Enterprises, hereinafter referred to as MSMEs, also have a role in overcoming unemployment, income distribution, increasing regional products and improving living standards. ${ }^{11}$

The sizeable role of MSMEs makes MSMEs a business actor that receives special attention from the government. In the Negative List of Investment contained in the attachment to Presidential Decree number 44 of 2016 concerning List of Closed Business Fields and Open Business Fields with Requirements in the Field of Investment, it lists certain fields in the Business List that are Open to Investors, but with good requirements which are Reserved for MSME or partnering with MSMEs. ${ }^{12}$ The above can be said as an effort to develop MSMEs.

Government efforts to develop MSMEs are also evident in the issuance of Government Regulation No. 23 of 2018 concerning Income Tax (PPh) on Income from Businesses Received or Obtained by Taxpayers who have a certain Gross Turnover. The regulation revised the final PPh for MSME entrepreneurs from the tariff of $1 \%$ to $0.5 \%$, the final $\mathrm{PPh}$ rate of $1 \%$ previously stated in PP No. 46 of 2013 that was imposed on individual taxpayers, cooperatives, limited partnership (CV), firms , or Limited Liability Company (PT). ${ }^{13}$

Development of MSME is not an easy thing, so in addition to the efforts mentioned above, other businesses need to be made. MSMEs have quite complex problems, where these problems are usually related in terms of limited business capital, inadequate human resource management, limited

9 V. D. H. Nugroho, "Literasi Akuntansi dan Pemasaran Online Bagi UMKM Desa Tirtonirmolo Kabupaten Bantul", Jurnal Keuangan Umum dan Akuntansi Terapan 1, no. 3 (2019): 190-193.

${ }^{10}$ U. A. H. K. Dewi, "Pengaruh Pembiayaan Mikro Syariah Terhadap Tingkat Perkembangan Usaha Mikro Kecil Menengah (UMKM) Pada Anggota BMT Di Jawa Barat”, Bongaya Journal for Research in Management Volume 2, no. 1 (2019): 48-56.

11 Muhammad, LKMS: Pergulatan Melawan Kemiskinan dan Penetrasi Ekonomi Global (Yogyakarta: Graha Ilmu, 2009), 35.

${ }^{12}$ Salviana, Fries Melia dan Desy Nurkristia Tejawati (Hukum Investasi. Surabaya: UWKS Press), 16.

${ }^{13}$ https://amp.kompas.com/, accessed on April 20, 2018. 
mastery of production technology, limited raw materials, and limited marketing expansion (marketing difficulties). ${ }^{14}$

Although the potential of MSMEs in Indonesia and East Java is quite large, there are still problems faced by MSMEs, namely the problem of capital and this is an obstacle to the development of these MSMEs. ${ }^{15}$

The reason why it is difficult for MSME players to get access to capital from banking institutions is due to the limitations of MSME players in providing quality financial reports. ${ }^{16}$

The process of recording financial reports is something that must be done by business actors, but the problem in society is that this process is a process that is considered to be cumbersome and adds to the work of MSME actors. ${ }^{17}$

This limited capital makes it difficult for MSME players to expand and develop their business. Besides, this problem also makes it difficult for players to develop their business market share. ${ }^{18}$

The MSME development program is packaged as a poverty alleviation program launched by the government, such as the Indeveloped Village Inpres, Mass Instruction, Farming Business Loans, Permanent Working Capital Loans, Small Investment Loans, Venture Capital, Small Business Loans, Fostering Improvement of Small Fishermen Farmer Income, Business Groups Together, the Coastal Community Economic Empowerment Program, Efforts to Increase Welfare Family Income, Food and Energy Security Credit, Revolving Funds, People's Business Credit, and others. But in fact the majority of these programs are less successful, except for the last type that is still running and is expected to be successful and sustainable. ${ }^{19}$

In the last few years, technological developments have begun to develop into the digital realm where this development is aimed at making Indonesia the largest digital economy country by 2024 , the government, which functions

\footnotetext{
${ }^{14}$ Sulistia Teguh, "Perlindungan Hukum dan Pemberdayaan Pengusaha Kecil dalam Ekonomi Pasar Bebas", Hukum Bisnis 27, no. 1 (2008): 1-7.

15 A. Abdianur, "Peningkatan UMKM Melalui Sosialisasi Laporan Keuangan Sederhana di Kelurahan Damai Baru Kecamatan Balikpapan Selatan", Jurnal Abdi Masyarakat Ilmu Ekonomi 1, no. 2 (2019): 60-65.

${ }^{16}$ Amir Hidayatulloh, L. N. Rintan Nuzul Ainy, "Peningkatan Akuntabilitas Keuangan Kelompok UMKM 'Aisyiah Bantul Melalui Pelatihan Pembukuan dan Perpajakan”, Jurnal Seminar Nasional Hasil Pengabdian Kepada Masyarakat, Universitas Ahmad Dahlan (2019): 681-686.

${ }^{17}$ F. N. Latifah, M. R. Maika, \& M. Masruchin, "Pembukuan dalam Perspektif Islam Studi Kasus Pembukuan Bagi Wirausaha Pemula Ibu Rumah Tangga Desa Kenongo", Jurnal Perisai: Islamic Banking and Finance 1, no. 2 (2017): 117-122, 117, DOI: 10.21070/perisai.v1i2.878

${ }^{18}$ R. Saadiah, "Peran Lembaga Keuangan Terhadap Pengembangan UMKM di Kota Malang". Jurnal Pangripta 2, no. 1 (2019): 321-332.

${ }^{19}$ Darwin, Dinamika MSME dan Pembiayaan Mikro dalam Septia, Yeni dan Nugroho. 2017. Pergulatan Program Kredit Mikro Dalam Mendorong Pengembangan MSME di Sektor Pertanian (Jakarta: LIPI Press, 2017), 2.
} 
as the country's economic regulator, must strive to empower Indonesian people from rural communities living in remote areas to participate. feel the impact of technological developments in the future. ${ }^{20}$

One of the innovations in technological development in business and economics, especially in the banking world, is the emergence of financial technology (Fintech) which has a function to facilitate all types of transactions including buying and selling, investing or collecting funds. ${ }^{21}$

Financial Technology, hereinafter referred to as fintech in Indonesia, has experienced quite rapid development, as of March 2018, the number of fintechs that have been registered with the Financial Services Authority, hereinafter referred to as OJK has reached 40 companies and out of that total there have been four fintech companies specializing in financing consumer.

The five fintech companies offer easy and easy installments for a variety of consumer goods, from fashion, gadgets, electronics, furniture, to household appliances, in addition to light installments, the loan approval process for credit approval is not more than one day. Compare with conventional companies, it takes 1-2 days. A fintech company called AwanTunai even claims it only takes 15 minutes. Awantunai is a fintech company that provides digital installment facilities, just by preparing an e-KTP, and waiting 15 minutes, prospective borrowers will get a credit limit of up to Rp. 5 - Rp. 19 million. ${ }^{22}$

The latest data states that the number of registered and licensed fintech companies with financial services authorities is 144 companies. $^{23}$

Fintech appears not only as an online financial transaction service but comes with many functions. Fintech in Indonesia is currently dominated by payment companies $(44 \%)$, aggregators $(15 \%)$, financing $(15 \%)$, personal financial planners $(10 \%)$, crowdfunding $(8 \%)$ and other forms $(8 \%){ }^{24}$

The number of Indonesians who currently have accounts at banks is $36 \%$ where there are still many people who do not have bank accounts and have not been touched by banking services, therefore fintech in Indonesia is here to

\footnotetext{
${ }^{20}$ I. M. A. R. G. Novalia, "Peran Fintech Dalam Meningkatkan Keuangan Inklusif Pada UMKM Di Indonesia (Pendekatan Keuangan Syariah)", Jurnal Ekonomi dan Perbankan Syariah 3, no. 1 (2018): 1-24, DOI: 10.30651/jms.v3i1.1618.

21 Muthiah Az-Zahra Rasyid \& I. Ro'fah Setyowati, "Crowdfunding Syariah Untuk Pengembangan Produk Perbankan Syariah Dari Perspektif Shariah Compliance", Diponegoro Law Journal 6, no. 4 (2017): 1-16.

${ }^{22}$ www.tirto.id, accessed on April 20, 2019.

${ }^{23}$ OJK, Perusahaan Fintech Lending Berizin Dan Terdaftar Di OJK per 30 September 2019. (September, 2019).

${ }^{24}$ Y. Manan, "Sistem Integrasi Proteksi \& Manajemen Resiko Platform Fintech peer to peer (P2P) Lending dan Payment Gateway untuk Meningkatkan Akslerasi Pertumbuhan UMKM 3.0", Journal of Islamic Economics, Finance, and Banking 2, no. 1 (2019): 73-87, DOI: 10.12928/ijiefb.v2i1.847.
} 
provide financial services that can be accessed by all levels of society who are untouched banking financial services. ${ }^{25}$

With the emergence of more fintechs, banks are currently changing their business model to a form of fintech that is aimed at creating new markets and enabling new technology-based services to be created. ${ }^{26}$ The fintech market in recent years has a potential where this is based on the fact that 49 million MSMEs still do not have access from banking financial institutions. ${ }^{27}$

The facilities of fintech that have been mentioned above, it is not excessive if the financing through fintech can overcome the problems faced by MSMEs.

Based on the background above, the following problems can be formulated: 1. What are the legal characteristics of financial technology as a financial institution? 2. What is the role of financial technology in financing MSME business capital?

\section{B. Discussion}

\section{Legal Characteristics of Financial Technology as a Financing Institution}

Civilizations according to the Big Indonesian Online Dictionary are: 1. Progress (intelligence, culture) physically and spiritually born, for example: "the nations of the world are not the same level of civilization" 2. Matters relating to manners, language, culture and culture nation. according to its history civilization ${ }^{28}$ is "World history is the history of mankind throughout the world, in all regions of the Earth, traced from the era of the Paleolithic (old stone age). In contrast to Earth's history (which includes Earth's geological history and eras before human existence), world history consists of archaeological studies and written records, from ancient times to the present.

Historical recording begins from the script and writing system was created, but the origin of civilization departed from the period before the creation of writing, or prehistoric times." ${ }^{29}$ A civilization is a journey of human life from a nation or region from time to time or from generation to generation, both related to the level of culture and level of knowledge, and does not rule out possibilities in terms of community life. And according to Jerinx in the Big Indonesian Dictionary, Civilization is: "When machines take over the world,

\footnotetext{
${ }^{25}$ R. N. Faih, "Analisis Transaksi Financial Technology (Fintech) Syariah dalam Perspektif Maqashid Syariah", Jurnal Ekonomi Dan Perbankan Syari'ah 6, no. 2 (2019): 167-175, DOI: 10.19105/iqtishadia.v6i2.

${ }^{26}$ B. J. D. S. Urbach, "Integrating the 'Troublemakers': A Taxonomy for Cooperation Between Banks and Fintechs", Journal of Economics and Business 2, no. 1 (2018): 26-42, DOI: 10.1016/j.jeconbus.2018.04.002.

${ }^{27}$ M. R. M. A. K. W. Isnawati, "Sistem Bagi Hasil Unit Usaha Ijabqabul.Id", Jurnal Studi Kasus Inovasi Ekonomi 03, no. 02 (2019): 25-30.

${ }^{28} \mathrm{https} / / /$ typoonline.com/kbbi/peradaban, accessed on Februari 15, 2020.

${ }^{29} \mathrm{https} / / /$ id.wikipedia.org/wiki/Sejarah_dunia, accessed on Februari 15, 2020.
} 
civilization dies"; 'Machine' means when we (humans) think like robots; without hearts." 30

Human civilization has always changed from century to century or from generation to the next generation since from prehistoric civilization to human civilization has known technology or machines, in prehistoric times humans already knew the name of the stone or bone age as a tool to help humans in their work and at the era of technology or machinery as a tool to help and facilitate and accelerate human work, then since human existence on this earth has been known whose name is to help humans to simplify and lighten and accelerate all of their jobs both heavy and light jobs, both large forms of work and small forms of work, everything has been done using tools to help the work that has been created by humans themselves, thus almost all human work in prehistoric and during sex. This charcoal has used tools in the form of technology that can lighten, simplify and accelerate human work.

The term civilization in its terminology is: "The term civilization is often used as a broader equation of the term" culture "which is popular in academia. Where every human being can participate in a culture, which can be interpreted as "art, customs, customs, beliefs, values, material behavior and habits in a tradition which is a way of life of society". However, in the most widely used definitions, civilization is a relatively complex and complex descriptive term for urban agriculture and culture. Civilization can be distinguished from other cultures by complexity and social organization and a variety of economic and cultural activities."

So that the changes that occur in the course of human life from generation before knowing the machine tool/science is renewable to the generation who is familiar with machine tools or technology.

Technology is one of the tools created by humans rather than a number of other tools that are equally created by humans at the present time, both technology in the form of machines, computers, and at the present time which has been widely known by the public in the media world social in the form of an operator or application provider, and the world of social media has entered into the lives of the community both young people and the elderly, and the operator or application provider referred to has been used in the fields of transportation, trade, aviation, learning and finance, all of which are inseparable from and become part of the application provider technology that took part in it, the technology in the form of application providers in the field of learning has now entered every field of learning both at the level of early childhood education up to the level of higher education, so that educational managers who do not enter the technical elements The logic in it will be left behind in the delivery of its learning and the results of its students who are

\footnotetext{
${ }^{30}$ https://jagokata.com/arti-kata/peradaban, accessed on Februari 15, 2020.
} 
issued or produced cannot compete both in the world of work and in the world of other competitions.

In the development of human life at this time will not be separated from technological civilization, according to Hikmahanto Juwana, said "technological development, which in Roger Filder's terms is called coexistence and coevolution. That human life cannot be separated from technological progress.

Dependence puts technology into a primary need and no longer secondary, so that technology is a necessity that can not be denied its presence. And then according to Franz Magnis-Suseno as Professor of Higher School Philosophy (STF) Diriyakara, it was said "there are two fundamental reasons why humans cannot reject technology. Namely: First, modern humans can not guarantee the fulfillment of their basic needs without the presence of technology. Secondly, the triumph of technological culture can no longer be frustrated. This makes humans do not have other alternatives besides having to learn at the same time mastering technology, and must use it to be able to solve the problems faced by humans.

Starting from this, there is no basis for the right to reject technology and technology has been accepted as part of human life. This makes humans have no other alternative but to learn and master the technology, and must use it to be able to solve the problems faced by humans. Starting from this, there is no basis for the right to reject technology and technology has been accepted as part of human life. ${ }^{31}$

People like it or not they have to continue to change from time to time or from generation to generation in another sense humans in their time are forced or forced to follow or become a necessity to follow a journey in their lives to not be able to refuse as part of his life journey So, if human beings prioritize their right to refuse existing conditions for the existence of life, then in their lives they will sink or be drowned by their time or drown by themselves so that eventually they will be eliminated from their existing life and slowly the sea of human will be left behind its time, "The acceptance of technology as an inseparable part of humanity departs from the history of human life itself, which is always trying to create technology to be able to meet its needs. Technology created by humans will always develop according to human civilization". so that the acceptance of artificial technology and use it as a tool to help its work is nothing but to simplify and expedite or accelerate in doing its work and will ultimately benefit back to humans themselves.

Humans will not be separated from the development of life in his era an example in the development of life in the stone age as a tool to help in his work then immediately all people who live and live in the area will gradually use the tools that were created, as well as at the time technology or machinery

\footnotetext{
${ }^{31}$ https://www. Kompasiana.com/juadimanullang, accessed on Februari 14, 2020.
} 
as a tool to help humans, it is certain that all people who live in the area concerned will use the technology.

The history of the development of human life from time to time that originally did not need finally became necessary, from the beginning that was not important became important, from the beginning only thought enough to eat alone and in the end wanted not to be eaten alone but thought to save or to multiply, from the beginning it is important just enough to complete one and in the end how if you can finish more and so on that is always influenced by the development of human life from the next generation of generation that continues to change from the journey of civilization in his life, "History of human civilization begins with a simple life. At first humans only needed food and shelter to support their lives from day to day, there was no future planning at that time.

Human life is developing more advanced and forming a civilization which according to Alfin Toffler in his book The Third Wave (William Morrow \& Company New York, 1980) into three waves of human civilization, namely: The first wave, which is also called the wave of renewal, humans find and apply agricultural technology. With that, people who originally lived to move to collect forest products become like living in a place that was then called a village.

The characteristic of this wave is that humans use energy that has been provided by nature, such as that found in animal muscles, sun, wind and water, all of which can be renewed. The second wave, namely the era of the industrial revolution marked the transition of human to non-renewable energy, such as oil, coal and gas.

In addition, in this period a machine has been invented, beginning with a steam engine, which can not only replace human muscles, but can also be integrated into a factory which then produces goods and consumer goods. The third wave, the information age marked by a civilization supported by advances in communication technology and also data processing, aviation and aerospace applications, alternative energy and renewable energy and genetic engineering and biotechnology, with computers and micro electronics as the basis of its core technology."32

In the current age of information or communication that has entered all lines of human work life must go hand in hand with the existence of human resources, thus the existence of qualified human resources must be a correlation between the existence of human resources with the existence of existing technology, for this reason it is possible to have training or higher education which must open a field of study program to prepare and provide the technology. The presence of technology is only limited to support teaching and learning in the classroom as a means of equitable quality education. if it

\footnotetext{
${ }^{32}$ https://business-law.binus.ac.id, accessed on Februari 15, 2020.
} 
can be considered at this time almost all fields of work in every country in the world have used technological tools as a tool to assist their work, and Indonesia has gradually also begun, both in the fields of aviation, transportation, shipping, education, trade and other financial sectors including those that have been carried out by a number of banks, especially the National banks, which are directly related to financial governance and the circulation of money to the public or better known as fintech or financial technology.

Financial Technology or Fintech are things and challenges that OJK must face in the midst of dynamic financial service sector innovations. Technology has changed the structure of the financial services industry.

Consumers and the public who are familiar with the internet and easy access to financial services through gadgets, have encouraged industry players to continue to create financial products and services that are easy, fast and convenient to use by utilizing technological developments. The active role of the relevant regulatory and supervisory authorities is necessary to develop regulations and oversee Fintech products and services while still paying attention to aspects of consumer protection". ${ }^{33}$

In a number of literatures found various definitions about FinTech. In general, and in a broad sense, FinTech refers to the use of technology to provide financial solutions. Specifically, FinTech is defined as the application of digital technology to financial intermediation problems. It can be compared; the progress of digitalization is running faster than the development of other sectors. More extreme it can be said that today the number of people who have a cell phone (cellphone) may be far greater than those who have access to electricity or clean water.

FinTech is defined as an industry consisting of companies that use technology to make the financial system and delivery of financial services more efficient. FinTech is also defined as technological innovation in financial services that can produce business models, applications, processes or products with material effects related to the provision of financial services. ${ }^{34}$

With the development of financial technology (fintech) to the citizens, in addition to the excitement because it can be facilitated in every financial sector, but also with the financial technology (fintech) the need to pay attention to the emergence of vulnerability for consumers or users of fintech itself if not careful, either directly or indirectly direct "Risk is the potential loss due to a particular event" (Article 1 number 2), "Compliance risk is the risk due to the Bank not complying with and/or not implementing the laws and regulations" (Article 1 number 8), "Legal Risk is Risk due to lawsuits and/or weaknesses in the juridical aspect "(Article 1 number 9) (PJOK

${ }^{33}$ Departemen Perlindungan Konsumen Otoritas Jasa Keuangan, Cetakan ke-1, Desember (2011).

${ }^{34}$ https://www.researchgate.net/publication/323629323Teknologi_Keuangan_Fintech_Konsep _dan Implementasinya di_Indonesia, accessed on Februari 20, 2020. 
No.18/POJK.03/2016 Concerning the Implementation of Risk Management for Commercial Banks), the development of fintech at this time besides bringing benefits and facilitating all in the financial sector will also pose a lot of risk and vulnerability if not heeded signs and inadvertence either as manager or user, if you really pay attention to the signs that have been determined by PJOK, then as a manager not only pay attention to the benefits to be obtained but also the risk of not returning capital or money to be obtained, and likewise as a fintech user does not necessarily accept what is offered by the fintech manager but must also pay attention to the signs that have been determined by PJOK so as not to fall into fintech itself not the benefits or benefits to be obtained but even vice versa the fortune of simply accepting it offered by fintech managers.

Besides having to pay attention to the risks that must be considered in the management and use of fintech, but also with the presence of fintech, it must really be able to reach out to all levels of society in order to really get service from the existence of fintech itself, so that it can really be felt for its existence and its benefits, in the background of SE No. 18/22/DKSP Regarding the Implementation of Digital Financial Services, said:

a. In order to reach out and expand the provision of payment and financial system services that are in accordance with the needs of the Indonesian people who have not been touched on by the payment system and formal financial services (unbanked) and who have been connected to the payment system and formal financial services as saver customers but have not utilized them in a way that optimal due to various factors (underbanked), it is necessary to innovate the use of Electronic Money as one of the instruments in DFS through cooperation with third parties in the form of agency; 1). The expansion of the provision of payment and financial system services is an initiative of Bank Indonesia in supporting the National Inclusive Financial Strategy, aimed at supporting economic activities and improving the welfare of individuals or households, as well as reducing poverty and income distribution;

b. One form of expansion of payment and financial system service provision is carried out in cooperation with the Issuer and DFS Agent. Therefore, it is necessary to regulate the implementation provisions regarding the implementation of DFS in the framework of financial inclusion through DFS Agencies.

The circular provides fintech so that all levels of society benefit and can be affordable financial services and improve the economy of the community both in rural and rural areas not only enjoyed by urban communities. Therefore, the financial services authority expects the existence of the intended fintech to be truly enjoyed by all Indonesian people in general and members of the lower class or lower middle-class economy can enjoy the fintech service. 
According to the Minister of PPN/Head of Bappenas Bambang P. S. Brodjonegoro said financial technology or more popularly referred to as Fintech, said in holding a workshop on the Role of Financial Technology in Development, ${ }^{35}$ In the Main Building of the Ministry of PPN/Bappenas, Minister Bambang explained three development priorities that could be driven by the use of Fintech, namely: First, capital mobilization to increase the economic activities of underserved groups, such as Low Income Communities (MBR) and Small and Medium Enterprises (SMEs), Second, mobilization of money in the community to finance basic infrastructure, such as sanitation and electricity. Third, mobilization of funds to encourage sustainable infrastructure development, such as clean energy, and/or finance innovations that are important in the context of increasing agricultural and fisheries production. "36

With the mobilization of these funds, according to the Minister of PPN/Bappenas not only benefits the economy of the lower middle class but also the distribution of these funds is channeled more quickly throughout the regions or remote areas that were previously difficult to reach with conventional fund distribution. With the faster distribution of funds, it has been ensured that the empowerment of a people's economy or an increase in the economy of the lower economic classes and more quickly elevate the dignity and status of lower-class economic families and will automatically empower the family.

Bank Indonesia's policy in implementing the fintech is in addition to the demand from the public but also because of the demands that must be done so that people's needs are related to the needs for capital in addition to continuing to grow as well as to be more quickly distributed to the public, in its Consideration, Bank Indonesia Regulation Number 18/40/Pbi/2016 Regarding the Implementation of Payment Transaction Processing, it is said: a) the development of technology and information systems continues to produce various innovations, especially those related to financial technology (fintech) in order to meet the needs of the community, including in the field of payment system services, both in terms of instruments, organizers, mechanism, as well as infrastructure for processing payment transactions; b). innovations in the implementation of payment transaction processing need to continue to support the creation of a payment system that is smooth, safe, efficient, and reliable, so it is necessary to regulate payment system service providers to complement existing provisions by prioritizing compliance with the principles of prudence and risk management adequate, and with due regard to expanding access, national interests and consumer protection, including

\footnotetext{
35 "Fintech untuk Pembangunan yang Inklusif dan Berkelanjutan", accessed on Februari 14, 2020.

${ }^{36}$ https://www.kemdikbud.go.id/main/blog/2017/05/fintech-instrumen-kolaboratif-untukcapai-pembangunan-inklusif-berkelanjutan-dan-berkeadila accessed on Februari 20, 2020. 
international standards and practices; c) in order to increase the resilience and competitiveness of the national payment system industry, Bank Indonesia needs to encourage the role of domestic players, among others through structuring the ownership structure of payment system service providers. All policies issued by Bank Indonesia to support government policies both at the Central and Regional levels for the creation of equity economy that can be enjoyed by all levels of Indonesian society.

The actual existence of Fintech is not to replace human existence or more clearly the existence of fintech cannot replace the actual condition and existence of human beings, but the existence of fintech is a complement or support of humans themselves to further accelerate, facilitate, ease and in other terms the existence of fintech at this time is only to support human work, in order to speed up work, simplify work, assist work and others that relate directly or indirectly to human work. And fintech will not and never replace humans themselves,

Fintech comes from the term financial technology. According to the National Digital Research Center (NDRC), fintech is an innovation in the financial sector. Of course, this financial innovation gets a touch of modern technology. The existence of fintech is expected to bring about a more practical and safer financial transaction process. This financial transaction process includes the payment process, the process of borrowing money, transferring, or selling beli saham.

Fintech can help overcome problems that cannot be worked on by conventional financial institutions, such as people who are not yet users of financial services. So the existence of fintech is expected to increase the appeal of the public towards financial products and services. Proving to the public that fintech makes everything more practical and efficient. ${ }^{37}$

The existence of fintech is not only aimed at the community directly or to people who need to be channeled more quickly, but with the existence of fintech, it supports Government programs both at the Central and Regional levels so that these Government programs are quickly realized to the community so that the economic empowerment of the community that is proclaimed by the Government still achieved, in SE BI No. 18/22/DKSP dated September 27, 2016 Regarding the Implementation of Digital Financial Services, to support the Government in facilitating Bank Indonesia for Publishers who have obtained licenses for the LKD implementation approval process, said, "Including national policy coverage if the application for the use and expansion of electronic money is intended among others in the framework of: 10 Supporting policies or initiatives or programs launched by the Central and Regional Governments, for example: distribution of social assistance and

37 Users/ACER/Downloads/Documents/Essay-Booklet-Access18, accessed on Februari 20, 2020 . 
subsidies; 20 Supporting policies or programs initiated by regulators in the framework of increasing financial inclusion or supporting Central Government policies or Programs and Regions, for example: expanding financial access for the financing community."

The support of the distribution of financial funds to the Central and Regional Governments by the Banking is very beneficial to the Government's policies that have been launched for the welfare of the community in general and the empowerment of the people's economy of the lower classes.

Fintech can now be present in all lines of work with the aim to simplify or accelerate human work, including the entry of fintech into the work of banking companies or other businesses, and all this with the presence of financial technology companies began with the emergence of Zopa in 2004, "Zopa is a UK-based peer-to-peer lending company founded in 2004 that has a banking license. It was launched in the UK in March 2005. Zopa was the first peer-topeer lender company. ${ }^{38}$ Financial institutions in the UK that offer money lending services. While in Indonesia, new fintech is in demand in 2016 and this business continues to grow endlessly.

The development of fintech in Indonesia itself can be said to be very fertile. Estimated to start appearing in 2006, in 2017 the Indonesian fintech industry The development of fintech in Indonesia has penetrated various sectors, ranging from payment startups, lending, financial planning (personal finance), investment, financing (crowdfunding), remittances, financial research , and others there are 4 factors the rapid development of fintech in Indonesia, namely: $:^{39}$

a. Fintech Provides Ease in Finance Fintech offers convenience and easy access for those who have not yet been reached by conventional financial products. Because fntech is based on the internet making fintech closely with young people who are very familiar with the internet and utilize the internet in their daily lives. So they consider fintech easier and more practical to use than conventional financial products.

b. Technology Development Along with the development of technology that is very fast, making fintech business people can continue to innovate continuously. If the market has new financial problems, fintech players can quickly provide innovative financial products that can solve these problems by properly utilizing the latest technological developments.

c. Millennials One factor in the rapid development of fintech in Indonesia is the generation of millennials. As we know, the millennials generation is a generation that has a very high entrepreneurial spirit. Why do many millennials choose fintech as their business? Because Fintech is still relatively new, there is still a high chance of entering and becoming

\footnotetext{
${ }^{38}$ https://en.wikipedia.org/wiki/Zopa, accessed on Februari 21, 2020.

$39 \mathrm{https} / / /$ www.dbs.com/spark/index/id_id/site/pillars/2018-rahasia-perkembangan-fintech-diindonesia-industri-digital-yang-sedang-berkembang-pesat, accessed on Februari 2, 2020.
} 
successful in it. Coupled with many success stories of fintech entrepreneurs who increasingly burn their spirits.

d. Flexible Fintech Business Assumptions The fintech industry is considered to be more flexible and not rigid compared to conventional financial businesses because there are still few regulations governing this one industry. That's why fintech is the right place for young business people. The development of fintech in Indonesia from year to year continues to grow and continues to grow from the types developed by several companies in Indonesia, besides that fintech has entered into several business fields that have been developed by several companies. Bank Indonesia classifies fintech into 4 groups of Bank Indonesia Regulation Number 18/40/Pbi/2016 concerning the Implementation of Payment Transaction Processing, namely:

Payment, Settlement, and Clearing, is a fintech category that provides payment system services for banks and $\mathrm{BI}$;

a. Market Aggregator, is a fintech that presents financial data so that users can use it as a comparison to choose the right financial product;

b. Risk Management and Investment, namely fintech which functions like a financial planner for users. So this fintech will help users choose financial products that are suitable for users;

c. Peer to Peer Lending (P2P Lending) is a fintech that offers direct loans to users at fixed rates.

Fintech in the country became a sexy business worth hundreds of trillions of rupiah because it offered several services, viz: loans (lending), payments, financial planning (Personal Finance), investment, financing (Crowdfunding), remittances, and financial research. Data from the Indonesian Fintech Association shows, the majority of fintech companies are currently engaged in P2P lending or direct loans and through direct money lending services, fintech companies can connect 2 (two) parties, namely: 1. Parties in need of funds or borrowers (Borrowers): Indonesian citizens (WNI) in the form of individuals or legal entities; and 2. Providers of funds (Investors): Indonesian Citizens and Foreign Citizens (foreigners) in the form of individuals, legal entities, and international institutions.

The rapid development of fintech at the present time the need for arrangements that must be very clear both to the user or user and to the provider of fintech itself so that both parties both get legal certainty and can be avoided abuse from fintech itself, and at this time there are many once a new fintech service that pops up both those that have been registered at your OJK and those that are not registered at the OJK, therefore the government as an agency has the authority or authority to and must provide legal signs so that the managers or providers of the fintechs that it manages are not misused so that cause or cause harm to the users of fintech itself. 


\section{The Role of Financial Institutions as an Alternative Source of Financing for MSMEs}

The role of financial institutions in the development of MSMEs in this analysis is divided into two parts. In running an MSME business, the MSMEs will need an initial capital. The amount of capital needed by SMEs in starting a business varies greatly depending on the type of business. The bigger and more complex the business, the more capital is needed. For MSME funding sources, meeting those needs varies. There are MSMEs that use 100\% personal capital from savings. There are also those who use $50 \%$ personal capital and another 50\% using loans. Sources of loans for MSME capital can come from family/relatives, friends and financial institutions. MSMEs in fulfilling capital need capital loans from financial institutions. Capital loans from regular MSME financing institutions assume to get larger MSME capital loans. When MSME actors determine a funding institution as an alternative source of funding, MSMEs must first consider access to loans, collateral, procedures, interest rates/profit sharing systems, information, trust and others.

Financial institutions as an alternative source of MSME financing are also included in the financial institution system. Because financial institutions can be divided into three categories, namely:

a. Bank financial institutions in accordance with Article 1 number 2 of the Law of the Republic of Indonesia Number 10 of 1998 concerning Amendment to Law Number 7 of 1992 concerning Banking, Banks are business entities that collect funds from the public in the form of deposits and distribute them to the public in the form of credit and or other forms in order to improve the lives of many people.

b. Non-bank financial institutions. Non-bank financial institutions are business entities that carry out activities in the financial sector that directly or indirectly raise funds by issuing securities and channeling them into the community to finance company investment. Business fields included in non-bank financial institutions include insurance, pawnshops, pension funds, mutual funds, financial institutions. Financial institutions are included in Non-Bank Financial Institutions (LKBB).

c. Financing Company is a business entity outside of a Bank and Non-Bank Financial Institution specifically established to carry out activities which are included in the business field, namely the Financing Institution.

Financial institutions are institutions that provide financial services for their customers, where in general these institutions are governed by financial regulations from the government. Concerning Definition of Financing Institutions is regulated in Article 1. Number 1. Presidential Regulation Number 9 of 2009 concerning Financing Institutions. What is meant by a financial institution is a business entity that carries out financing activities in 
the form of funds or capital goods. ${ }^{40}$ Because this financial institution is a business entity that carries out financing activities in the form of providing funds or capital goods without withdrawing funds directly from the public. Financial institutions are also widely used by MSMEs for alternative solutions as an effort to develop their business. Regarding the regulations of financial institutions that were formed based on the provisions contained in:

a. Civil law code;

b. Law number 17 of 2012 concerning cooperatives;

c. Law number 40 of 2007 concerning limited liability companies;

d. Law number 21 of 2011 concerning limited service authorities;

e. Presidential Regulation number 9 of 2009 concerning financial institutions;

f. Minister of finance regulation number 74/PMK.021/2006. concerning the application of the principle of getting to know customers for non-bank financial institutions;

g. Regulation of the minister of finance number 84/PMK.012/2006. concerning finance companies.

The function of financing institutions has quite an important role, namely as an alternative funding source to support the growth of national MSMEs, accommodate, channel the aspirations and interests of the community and play an important role in improving and developing MSMEs, where these institutions are expected by the public and as MSMEs actors to overcome common problems namely from in terms of capital. For the types of financing institutions, it is regulated in Article 2 of the Republic of Indonesia Presidential Regulation Number 9 of 2009 concerning financing institutions, namely:

a. Financing Company is a business entity that is specifically established to undertake Leasing, Factoring, Consumer Financing, or Credit Card business.

b. Venture Capital Company is a business entity that carries out business financing/equity participation in a company that receives financing assistance (investee Company) for a certain period of time in the form of equity participation, participation through the purchase of convertible bonds, and or financing based on the distribution of operating results, and

c. Infrastructure Financing Company, which is a business entity that was established specifically to conduct funding in the form of providing funds for infrastructure projects.

Financing institutions as an alternative source of MSME financing. To provide financial support in accordance with the needs of MSMEs. according to Bank Indonesia capital financing for MSMEs can be divided into 2 (two) categories, namely: Micro Financial Institutions (LKM) in the form of Micro

\footnotetext{
${ }^{40}$ Ahmad Muliadi, Hukum Lembaga Pembiayaan (Jakarta: Academia Permata, 2013), 4.
} 
Financial Institutions (MFIs) from banks and Micro Financial Institutions (MFIs) not from banks.

\section{The role of Financial Technology (Fintech) in MSME financing institutions}

The existence of the Financial Technology (Fintech) financing agency was welcomed by the government and regulators such as the Financial Services Authority (OJK). The function of the Financial Services Authority in Peer to Peer Lending (P2P Lending) financial services, namely Financial Technology (Fintech) is pursued as a growth driver and oversees fintech financial institutions by mitigating risk/risk management in lending and borrowing money services based on information technology or Peer to Peer Lending ( $\mathrm{P} 2 \mathrm{P}$ Lending) regulated in OJK Regulation Number 77/POJK.01/2016. The Financial Services Authority (OJK) will prepare more regulations regarding the regulation of Financial Technology (Fintech) specifically so that fintech institutions in Indonesia have a clear legal status and complete in its technical arrangements. This Fintech financial institution is an extension of financial technology. According to Hsueh, financial technology is also referred to as fintech, a new financial service model developed through information technology innovation. ${ }^{41}$

The point is the Financial Technology (Fintech) financing institution is a type of legal entity in the financial services/financing sector that uses information technology. Financial Technology (Fintech) is the use of information technology in a financial system that produces new products, services, technology and/or business models and can have an impact on monetary stability, financial system stability, and/or the efficiency, smoothness, security and reliability of payment systems regulated in Article 1 of Bank Indonesia Regulation No. 19/12/PBI/2017 concerning Implementation of Financial Technology (PBI Tekfin) and Law No. 19 of 2016 in conjunction with Law No. 11 of 2008 concerning Information Technology, here in after referred to as ITE Law.

The Financial Technology (Fintech) financing system provides an easy way for MSMEs to obtain capital loan services. Financial Technology (Fintech) offers convenience in capital loan services so that the filing process is easier, practical and efficient compared to conventional financial institutions such as banks/non-bank financial institutions. The credit agreement documents used are electronic documents as contained in article 1 angka 12 of the Fintec Credit POJK. Thus giving birth to agreements online or based on information technology in the financial services sector. Excellence in online agreements in the implementation of the agreement agreement

\footnotetext{
${ }^{41}$ Hsueh. "Effect of Fintech on the Productivity in The Taiwan Banking Industry". IJEEE 7, no 4, 2017: 255-263, 256, DOI: 10.17706/ijeeee.2017.7.4.255-263.
} 
carried out online and the subjects do not meet with each other. This agreement is made between the financial service provider and the loan/debtor recipient regulated in accordance with Article 1 number 6 Fintech Credit POJK. The ease of financing this Financial Technology (Fintech) can be seen in the application for capital loan applications. In the application at Financial Technology (Fintech), it is also offered a service process for how to pay capital loans digitally. In the application system Financial Technology (Fintech) also provides features on how to manage business finance for MSME business development. Financial Technology Financial Institution (Fintech) in an effort to improve and develop MSMEs. Bank Indonesia has regulated how Financial Technology (Fintech) institutions improve and develop MSMEs in Bank Indonesia Regulation number 14/22/PBI/2012 concerning lending or financing and technical assistance in the context of developing micro, small and medium businesses.

So that Financial Technology (Fintech) as a financial institution is required to provide technical assistance in the form of assistance in making budgets, recording expenses, periodic reports, and conducting free financial consultations. Financial Technology (Fintech) in providing guidance and assistance to MSMEs is strived to be able to encourage the transmission of economic policies and be able to increase the velocity of money so as to improve the people's economy. Financial Technology (Fintech) as an alternative financial institution in MSME capital financing such as the role of conventional financial institutions. The Financial Technology Institute (Fintech) has a role in providing the trading market for MSME products as mandated by Bank Indonesia regulations on providing technical assistance. So MSME has no difficulty in marketing its products to the trading market. If the MSME business is successful in marketing its products, it can help MSME in making payments, settlement/settlement of capital loan repayments and Helping MSMEs to avoid payment defaults or bad loans in the process of repaying capital loans.

MSMEs in the repayment/settlement of capital loan repayments in Financial Technology (Fintech) have been regulated in the payment system in Indonesia, namely:

a. Bank Indonesia Regulation No. 18/40/PBI/2016 concerning Implementation of Payment Transaction Processing.

b. Circular of Bank Indonesia No. 18/22/DKSP regarding the Implementation of Digital Financial Services.

c. Bank Indonesia Regulation No. 18/17/PBI/2016 concerning Electronic Money.

d. Regulation of the Financial Services Authority Number 77/Pojk.01/2016 Concerning Information Technology Lending and Borrowing Services

The influence of technological sophistication in the payment system encourages Bank Indonesia as the central bank of the Republic of Indonesia 
to ensure payment traffic that has been penetrated by technology continues in an orderly and safe manner and supports the pillars in achieving the vision and mission of Bank Indonesia.

\section{Financial Technology (Fintech) as a Literacy Source for MSME Financing}

Financial Technology (Fintech) is now increasingly developing as a financing institution related to technology. So that the ease of Financial Technology (Fintech) in really helping MSMEs get capital. But the SMEs in knowing Financial Technology (Fintech) information is still limited, not many know what are the functions and roles of Financial Technology (Fintech). Financial Technology (Fintech) has many roles not only as capital financing and financial regulator. But Financial Technology (Fintech) as a Source of Funding Literacy due to: ${ }^{42}$

a. Developments in Financial Technology (Fintech) Technological advancements have pushed the development of Financial Technology (Fintech) in financial institutions including banks, savings and loan cooperatives and other financial institutions to improve service features. The increase will facilitate application users, namely the SMEs.

b. Consumer Consumer behavior is now due to technological developments changing the habits of the community that used to be conventional to online, in addition to simplifying transactions can also be practically done without coming directly. This affects the sale of products so that MSME owners are inevitably required to use Fintech as a transaction tool.

c. Comfort and Security The development of Fintech is equipped with sophisticated security in the application so that the level of security and comfort is better compared to manual transactions.

MSMEs in Financial Technology (Fintech) are encouraged to be able to transact without having to worry about security. Because data security in transactions in Financial Technology (Fintech) has been guaranteed in Collaboration between banking and Financial Technology (Fintech). So that it can contribute in increasing financial literacy by MSMEs. The Financial Services Authority (OJK) states that the important mission of the financial literacy program is to carry out education in the field of finance to the people of Indonesia in order to manage finances smartly, so that the low level of knowledge about the financial industry can be overcome and the public is not easily fooled into investment products that offer high profits in the short term without considering the risks. ${ }^{43}$

\footnotetext{
${ }^{42}$ https://stiealwashliyahsibolga.ac.id/jurnal/index.php/jesya/article/view/132/78, accessed on Februari 17, 2020.

${ }^{43}$ ojk.go.id/id/kanal/edukasi-dan-perlindungan-konsumen/Pages/Literasi-Keuangan.aspx, accessed on Februari 17, 2020.
} 
To ensure public understanding of the products and services offered by financial institutions, the public is expected to be more selective in choosing a legal position in financial technology financial institutions (Fintech). The public/MSMEs are expected to seek information first about the legal position of the Financial Services (Fintech) financial services institutions that are already registered or not yet registered with the Financial Services Authority (OJK). lack of information or understanding of the community/MSMEs about the legal position of the Financial Technology (Fintech) financing institution, resulting in the community/loss will suffer a loss in the future.

So that the government created a national strategy program for financial literacy that launched three main pillars. First, promoting education programs and national financial literacy campaigns. Second, in the form of strengthening financial literacy infrastructure. Third, talk about developing affordable financial products and services. The application of the three pillars is expected to realize Indonesian people who have a high level of financial literacy so that people can choose and utilize financial service products to improve welfare. ${ }^{44}$

\section{Conclusion}

Characteristics of Financial Technology As a Financial Institution that uses information technology to provide financial solutions by prioritizing compliance with the principles of prudence and risk management. The characteristics of Financial Technology institutions are getting a loan quickly; Makes Payment Easier; Make loan payments without additional costs; Fintech as an Investment Facility; Fintech Helps Manage Finances Better; and Fintech can help the economic growth of lower middle class economic groups, including students. so that Fintech can help Manage Finances Better. For the Fintech Monitoring and Supervision Mechanism, a regulation is needed to support or anticipate the existence of existing finteches, therefore the Financial Services Authority must be fully and anticipated to avoid abuse. The Financial Services Authority instructs IKD organizers to be required to independently monitor by compiling a self assessment report that at least contains aspects of governance and risk mitigation.

In order to increase the empowerment of MSMEs. the Indonesian government issued 2 (two) policies on MSME capital financing through bank financing institutions, including: a. People's Business Credit (KUR); b. Bank Indonesia Policy. This government policy is expected to play the role of financial institutions in the development of MSMEs as financial institutions

\footnotetext{
${ }^{44}$ Dwi Latifiana, "Studi Literasi Keuangan Pengelola Usaha Kecil Menengah (UKM)", Prosiding Seminar Pendidikan dan Bisnis 3, no. 1 (2017): 1-7.
} 
as an alternative source of financing. This microfinance institution (LKM) is able to be an alternative solution for the community to develop more advanced MSMEs with the ease of obtaining business capital loans. The main mission of microfinance institutions (LKM) is to improve access to capital financing for MSMEs. the concept of microfinance institutions (MFIs) there are also information technology-based loan services, namely the Peer to Peer Lending (P2P lending) system. Peer to Peer Lending (P2P lending) system in providing financial services is done through information technology based. The financial services institution Peer to Peer Lending (P2P Lending) is a financial technology financial institution (Fintech). Financial Technology (Fintech) is the use of information technology in a financial system that produces new products, services, technology and/or business models and can have an impact on monetary stability, financial system stability, and/or efficiency, fluency, security. Financial Technology (Fintech) as Literacy for MSME Financing Sources; Financial Technology (Fintech) As a Facilitator in MSME Development; Financial Tecnology (Fintech) as a driver of MSMEs to Increase National Financial Inclusion. The Role of the Financial Services Authority (OJK) and the Indonesian Joint Funding Fintech Association (AFPI) As Regulations and Oversight of Financial Technology Institutions (Fintech) in Indonesia.

\section{References}

Abdianur, A. "Peningkatan UMKM Melalui Sosialisasi Laporan Keuangan Sederhana di Kelurahan Damai Baru Kecamatan Balikpapan Selatan". Jurnal Abdi Masyarakat Ilmu Ekonomi 1, no. 2 2019: 60-65.

Amalia, Lia. Ekonomi Pembangunan. Yogyakarta: Graha Ilmu, 2007.

Darwin. Dinamika MSME dan Pembiayaan Mikro dalam Septia, Yeni dan Nugroho, 2017, Pergulatan Program Kredit Mikro Dalam Mendorong Pengembangan MSME di Sektor Pertanian. Jakarta: LIPI Press, 2017. Departemen Perlindungan Konsume dan Otoritas Jasa Keuangan, Cetakan ke1, Desember 2019.

Dewi, U. A. H. K. "Pengaruh Pembiayaan Mikro Syariah Terhadap Tingkat Perkembangan Usaha Mikro Kecil Menengah (UMKM) Pada Anggota BMT di Jawa Barat". Bongaya Journal for Research in Management Volume 2, no. 1 (2019): 48-56.

Dorfleitner, Hornuf, Schmitt, dan Weber. Fintech in Germany. Berlin: Springer, Berlin, 2017.

Faih, R.N. "Analisis Transaksi Financial Technology (Fintech) Syariah dalam Perspektif Maqashid Syariah". Jurnal Ekonomi dan Perbankan Syari'ah 6, no. 2, 2019: 167-175, DOI: 10.19105/iqtishadia.v6i2. 
Financial Services Authority Circular Letter (SEOJK), SEOJK Number 29/SEOJK.05/2015 concerning Financial Statements of Micro Financial Institutions.

Financial Services Authority Number 13/POJK.05/2014 concerning Microfinance Institution Business Operations.

Financial Services Authority Regulation (POJK) Number 12/POJK.05/2014 concerning Business Licensing and Institutional Microfinance Institutions.

Financial Services Authority Regulation (POJK) Number 13/POJK.05/2014 concerning Microfinance Institution Business Operations.

Financial Services Authority Regulation (POJK) Number 14/POJK.05/2014 concerning Development and Supervision of Micro Financial Institutions.

Financial Services Authority Regulation (POJK) Number 61/POJK.05/2015 concerning Amendments to the Financial Services Authority Regulation Number 12/POJK.05/2014 concerning Business Licensing and Institutional Microfinance Institutions.

Financial Services Authority Regulation (POJK) Number 62/POJK.05/2015 concerning Amendments to Regulations

Government Regulation Number 89 of 2014 concerning Loan Interest Rates or Financing Returns and the Area of Microfinance Institutions' Business Areas.

Hanitijo, Ronny. Metodologi Penelitian Hukum dan Jurimetri. Jakarta: Ghalia Indonesia, 1994.

Hidayatulloh, Amir., Rintan Nuzul Ainy, L.N. "Peningkatan Akuntabilitas Keuangan Kelompok UMKM 'Aisyiah Bantul Melalui Pelatihan Pembukuan dan Perpajakan". Jurnal Seminar Nasional Hasil Pengabdian Kepada Masyarakat, Universitas Ahmad Dahlan, 2019: 681-686.

Hsueh. "Effect of Fintech on the Productivity in The Taiwan Banking Industry". IJEEE 7, no 4, 2017: 255-263, DOI: 10.17706/ijeeee.2017.7.4.255-263.

http://www.depkop.go.id/uploads/tx_rtgfiles/01._Paparan_Sekretaris_Keme nterian_KUKM_02.pdf., Accessed on April 20, 2018.

https://amp.kompas.com/, accessed on April 20, 2018.

https://business-law.binus.ac.id, accessed on Februari 15, 2020.

https://jagokata.com/arti-kata/peradaban, accessed on Februari 15, 2020.

https://stiealwashliyahsibolga.ac.id/jurnal/index.php/jesya/article/view/132/7

8, accessed on Februari 17, 2020.

https://typoonline.com/kbbi/peradaban, accessed on Februari 15, 2020.

https://www. Kompasiana.com/juadimanullang, accessed on Februari 14, 2020. 
https://www.dbs.com/spark/index/id_id/site/pillars/2018-rahasia-

perkembangan-fintech-di-indonesia-industri-digital-yang-sedang-

berkembang-pesat, accessed on Februari 2, 2020.

https://www.kemdikbud.go.id/main/blog/2017/05/fintech-instrumen-

kolaboratif-untuk-capai-pembangunan-inklusif-berkelanjutan-dan-

berkeadila, accessed on Februari 20, 2020.

Isnawati, M. R. M. A. K. W. "Sistem Bagi Hasil Unit Usaha Ijabqabul.Id".

Jurnal Studi Kasus Inovasi Ekonomi 03, no. 02, 2019: 25-30.

Latifah, F. N., Maika, M. R. \& Masruchin, M. "Pembukuan dalam Perspektif

Islam Studi Kasus Pembukuan Bagi Wirausaha Pemula Ibu Rumah

Tangga Desa Kenongo". Jurnal Perisai: Islamic Banking and Finance

1, no. 2: 117-122, DOI: $10.21070 /$ perisai.v1i2.878

Latifiana, Dwi. "Studi Literasi Keuangan Pengelola Usaha Kecil Menengah

(UKM)", Prosiding Seminar Pendidikan dan Bisnis 3, no. 1, 2017: 1-7.

Law Number 1 of 2013 concerning Microfinance Institutions.

Luckandi, D. "Analisis Transaksi Pembayaran Menggunakan Fintech Pada

UMKM di Indonesia: Pendekatan Adaptive Structuration Theory".

Jurnal Informatika Dan Komputer 4, no. 1, 2019: 1-10.

Manan, Y. "Sistem Integrasi Proteksi \& Manajemen Resiko Platform Fintech

Peer to Peer (P2P) Lending dan Payment Gateway untuk Meningkatkan

Akslerasi Pertumbuhan UMKM 3.0". Journal of Islamic Economics,

Finance, and Banking 2, no. 1, 2019: 73-87, DOI: 10.12928/ijiefb.v2i1.847.

Muhammad. LKMS: Pergulatan Melawan Kemiskinan Dan Penetrasi Ekonomi Global. Yogyakarta: Graha Ilmu, 2009.

Muliadi, Ahmad. Hukum Lembaga Pembiayaan. Cet. I. Jakarta: Academia Permata, 2013.

Muthiah Az-Zahra Rasyid \& Ro'fah Setyowati, I. “Crowdfunding Syariah Untuk Pengembangan Produk Perbankan Syariah Dari Perspektif Shariah Compliance". Diponegoro Law Journal 6, no. 4, 2017: 1-16.

Nitisusastro, Mulyadi. Kewirausahaan dan Manajemen Usaha kecil, Cet II. Bandung: Alfabeta, 2012.

Nitisusastro, Mulyadi. Kewirausahaan dan Manajemen Usaha kecil, Cet II. Bandung: Alfabeta, 2012.

Novalia, I. M. A. R. G. "Peran Fintech Dalam Meningkatkan Keuangan Inklusif Pada UMKM di Indonesia (Pendekatan Keuangan Syariah)".

Jurnal Ekonomi dan Perbankan Syariah 3, no. 1, 2018: 1-24. DOI: 10.30651/jms.v3i1.1618

Nugroho, V. D. H. "Literasi Akuntansi dan Pemasaran Online Bagi Umkm Desa Tirtonirmolo Kabupaten Bantul". Jurnal Keuangan Umum Dan Akuntansi Terapan 1, no. 3, 2019: 190-193.

OJK. Perusahaan Fintech Lending Berizin dan Terdaftar Di OJK per 30 September 2019. September, 2019. 
ojk.go.id/id/kanal/edukasi-dan-perlindungan-konsumen/Pages/Literasi-

Keuangan.aspx, accessed on Februari 17, 2020.

Rahardjo, R. M. K. "Faktor Pendukung Keputusan Umkm Dalam Mengambil

Modal Usaha Dengan Model Peer-To-Peer (P2p) Lending”. Jurnal

Nasional Edusainstek 2, no. 1, 2019: 438-445.

Saadiah, R. "Peran Lembaga Keuangan Terhadap Pengembangan Umkm Di

Kota Malang". Jurnal Pangripta 2, no. 1, 2019: 321-332

Salviana, Fries Melia dan Desy Nurkristia Tejawati. Hukum Investasi. Surabaya: UWKS Press, 2018.

Setiawan, N. V. F. A. "Peran Keunggulan Bersaing Dalam Memediasi

Dampak Orientasi Pasar Dan Orientasi Kewirausahaan Terhadap Kinerja UMKM". Majalah Ilmiah 18, no. 1, 2018: 54-70, DOI: 10.1017/CBO9781107415324.004.

Siamat, Dahlan. Manajemen Lembaga Keuangan, Edisi Kedua. Jakarta: Fakultas Ekonomi Universitas Indonesia, 2001.

Soekanto, Soerjono. Pengantar Penelitian Hukum. Jakarta: Universitas Indonesia Press, 1989.

Sucahyawati, A. H. K. "Dimensi Kreativitas dan Pengembangan Usaha Mikro Kecil dan Menengah (UMKM)". Jurnal Hummansi 2, no. 1, 2019: 2536.

Sulistia, Teguh. "Perlindungan Hukum dan Pemberdayaan Pengusaha Kecil dalam Ekonomi Pasar Bebas". Hukum Bisnis 27, no. 1, 2008: 1-7.

Tulus T. Dan H. Tambunan. Usaha Mikro, Kecil dan Menengah. Jakarta: Ghalia Indonesia, 2017.

Urbach, B. J. D. S. "Integrating the 'Troublemakers': A taxonomy for Cooperation Between Banks and Fintechs". Journal of Economics and Business 2, no. 1, 2018: 26-42, DOI: 10.1016/j.jeconbus.2018.04.002.

Users/ACER/Downloads/Documents/Essay-Booklet-Access18, accessed on Februari 20, 2020.

www.google.com/amp/s/m.liputan6.com/amp/3581067/, Accessed on April 20, 2018.

www.google.com/amp/s/m.liputan6.com/amp/3581067/, Accessed on April $20,2018$.

www.tirto.id, accessed on April 20, 2019. 
